\title{
A ÉtICA dA MONOGAMIA E O ESPÍRITO DO FEMINICÍDIO: marxismo, patriarcado e adultério na
Roma Antiga e no Brasil Atual
}

The Ethics of Monogamy and the Spirt of Feminicide: Marxism, Patriarchy and Adultery in Ancient Rome and in Current Brazil

\section{RESUMO}

A partir do tema da criminalização do adultério feminino, este artigo apresenta algumas questões do debate conceitual em torno do termo "patriarcado", principalmente aquelas debatidas por Engels e autoras marxistas do século $X X$. O contexto patriarcal romano da época augustana é discutido com o objetivo de apontar especificidades históricas de realidades distintas que se dialogam. Nesse sentido, elementos do Direito Romano e do Direito Penal Brasileiro são analisados para uma breve discussão sobre violência contra a mulher e feminicídio.

Palavras-chave: patriarcado, adultério, direito romano, feminicídio.

\begin{abstract}
This article discusses the criminalization of female adultery by presenting some questions on the conceptual debate around the term 'patriarchy', especially those debated by Engels and Marxist female authors of the $20^{\text {th }}$ century. The Roman patriarchal context of the Augustan period is discussed to point out historical specificities of different realities that dialogue. In this sense, elements of Roman Law and Brazilian Criminal Law are analysed for a brief discussion on violence against women and feminicide.
\end{abstract}

Keywords: patriarchy, adultery, roman law, feminicide. 
Contra o adultério, como contra a morte, não há remédio que valha

(ENGELS, 1891, p. 76)

\begin{abstract}
Toda reflexão moral, por mais teórica, por mais geral que seja, toda questão moral, por mais contemporânea que seja, não pode evitar, me parece, uma questão histórica que lhe está associada, que é sua sombra projetada e que seria: o que aconteceu no primeiro século de nossa era, no ponto de viragem do que chamamos de uma ética pagã e uma moral cristã? Na história de nossa moral, esse problema histórico está associado a toda questão geral ou a toda questão política referente à nossa moral. (FOUCAULT, 2016, p. 19)
\end{abstract}

$\square$ oucault defende que grandes questões teóricas estão associadas a questões históricas, e destaca que para uma formulação teórica sobre a moral sexual contemporânea se faz necessário compreender certos eventos ocorridos em um período específico da Antiguidade: o primeiro século. Repetindo as palavras de Foucault: "O que aconteceu no primeiro século de nossa era, no ponto de viragem do que chamamos de uma ética pagã e uma moral cristã?".

O primeiro século de nossa era corresponde ao primeiro século do Império Romano. O ano 1 d.C. corresponde ao ano 753 para os romanos que, então, assistiam à consolidação da transição entre o regime republicano para o regime imperial, efetuada por Augusto, primeiro imperador de Roma. No ano 1 d.C. Augusto já estava no poder há 27 anos, e havia feito inúmeras reformas em toda a estrutura política, social e espacial romana, projetando a cidade de Roma como o centro de um Império duradouro.

Uma dessas reformas é conhecida como a 'reforma moral' de Augusto, que consistiu basicamente na promulgação de uma legislação que regia sobre as relações matrimoniais e extramatrimoniais. Essa legislação foi composta por três leis: Lei Júlia sobre o adultério (Lex Iulia de adulteriis), Lei Júlia sobre as ordens matrimoniais (Lex Iulia de maritandis ordinibus) e Lei Papia-Popeia (Lex Pappia Popaea).

Hoje conhecidas como 'Leis matrimoniais de Augusto', a legislação teve como objetivo uma reorganização social da aristocracia romana. Tal reorganização foi pautada por uma delimitação e incorporação de certos costumes nas leis. Deste modo, podese dizer que não foi uma reorganização completa, por ter reafirmado e reconhecido certos costumes já existentes. Entretanto, a validação de alguns costumes pela lei incorreu na invalidação de outros costumes, de modo que certas práticas perderam sua legitimidade, provocando estranhamento e reação por parte da aristocracia. Esta reação é caracterizada por uma ideia de interferência ilegítima do governante principalmente porque ele transferiu para a esfera pública muitos dos mecanismos que pertenciam à ordem privada e doméstica, acarretando em uma reconfiguração das funções, direitos e deveres do pater familias. 
As leis representavam um esquema de punição e recompensa com fins de estimular determinados comportamentos individuais relacionados ao casamento e à procriação. Homens e mulheres casados e com filhos eram privilegiados. Por exemplo, nos casais com no mínimo três filhos, os homens poderiam acelerar a carreira política assumindo cargos antes da idade fixada para tal, e as mulheres poderiam ser liberadas da tutela masculina.

A legislação era abrangente e determinava sobre o casamento e sobre as relações extraconjugais como adultério e prostituição. Toda a legislação ia no sentido de fixar categorias sexuais (matronas $X$ prostitutas) e fronteiras hierárquicas de fundo patriarcal. A 'Lei Júlia sobre adultério' apresentava um ritual processual que procurava anular a figura transitória e indesejada da adúltera, transformando-a em uma prostituta. A adúltera deveria ser expurgada de maneira definitiva ou se transformar em uma prostituta, a existência de uma matrona adúltera era uma contradição que precisava ser anulada.

A dicotomia matronas $X$ prostitutas se apresenta de várias formas em contextos patriarcais. Tal dicotomia, baseada em uma ideia de honra em termos sexuais, é essencial para a dinâmica da dominação masculina, uma vez que coloca o homem e o sexo como fatores de regulação do acesso das mulheres aos recursos para a sobrevivência. Ou seja, esta dicotomia informa que uma mulher deve garantir recursos se vinculando a um homem (pai ou marido) ou a um ou mais homens, por meio da prostituição, atividade que adquire diferentes significados ao longo do tempo e do espaço.

O patriarcado romano, assim como outros patriarcados da Antiguidade, vem servindo como referência para se pensar em uma ética monogâmica baseada na ideia de posse, dominação e violência. Podemos dizer que um dos precursores deste debate é Engels, que, a partir de uma perspectiva evolutiva, situa os patriarcados antigos como pertencentes a uma fase da civilização ocidental rumo à família burguesa. Esta proposição é explorada por Engels em A origem da familia, da propriedade privada e do Estado (1891), ao postular, por meio da análise das forças produtivas, que o patriarcado teria surgido a partir do desenvolvimento de técnicas agrícolas e pastorais, que levaram a uma produção de excedentes os quais os homens passaram a controlar e comercializar. A regulamentação do corpo feminino, então, passaria a ter importância na medida em que surge no homem a preocupação em manter a propriedade. A questão da sucessão passa a ser fundamental como forma de preservar a propriedade na unidade familiar. Entretanto, é a sucessão patrilinear que se consolida como predominante, em detrimento da sucessão matrilinear, em voga em período anterior. A propriedade e o poder se passa de pai para filho, e as mulheres passam a assumir a função de gerar uma descendência legítima em termos patrilineares somente.

Nas palavras de Engels, a família monogâmica:

Baseia-se no predomínio do homem; sua finalidade expressa é a de procriar filhos cuja paternidade seja indiscutível; e exige-se essa paternidade indiscutível porque os filhos, na qualidade de herdeiros diretos, entrarão, um dia, na posse dos bens de seu pai (ENGELS, 1891 p. 66). 
Engels aponta que o surgimento da monogamia pode ser visto como um dos primeiros sinais de divisão de classes. Nesse sentido, afirma que:

O primeiro antagonismo de classes que apareceu na história coincide com o desenvolvimento do antagonismo entre o homem e a mulher na monogamia; e a primeira opressão de classes, com a opressão do sexo feminino pelo masculino (Ibid. p. 70-71).

Engels afirma que a monogamia se revestiu de várias formas ao longo do tempo, e que nesse processo é possível perceber certos fenômenos constantes que se configuraram como características típicas dessa instituição. Dois desses fenômenos se fazem importantes aqui: 1. o fato de a monogamia ser estabelecida somente para as mulheres; 2 . o adultério.

Engels classifica esses dois fenômenos como duas contradições subjacentes à monogamia. Sobre o primeiro fenômeno, Engels o define de forma indireta ao utilizarse do termo 'heterismo'. Trata-se de um termo para designar relações extraconjugais de homens com mulheres não casadas. Ao analisar esse fenômeno, Engels indica que "o heterismo mantém a antiga liberdade sexual" somente para os homens, de forma que a monogamia foi instituída unicamente para as mulheres. A prostituição feminina e a manutenção de escravas e concubinas, nesse sentido, se configuram como elementos que asseguram o funcionamento do heterismo. Sobre o segundo fenômeno, o adultério, Engels o define como uma consequência do heterismo:

\begin{abstract}
Junto do marido, que amenizava a existência com o heterismo, acha-se a esposa abandonada. E não pode haver um termo de uma contradição sem que lhe corresponda o outro, como não se pode ter nas mãos uma maçã inteira, depois de se ter comido sua metade. Esta, no entanto, parece ter sido a opinião dos homens, até que as mulheres Ihes puseram outra coisa na cabeça. Com a monogamia, apareceram duas figuras sociais constantes e características: o inevitável amante da mulher casada e o marido corneado. Os homens haviam conseguido vencer as mulheres, mas as vencidas se encarregaram, generosamente, de coroar os vencedores. O adultério, proibido e punido rigorosamente, mas irreprimível, chegou a ser uma instituição social inevitável, junto à monogamia e ao heterismo. No melhor dos casos, a certeza da paternidade baseava-se agora, como antes, no convencimento moral, e para resolver a contradição insolúvel o Código de Napoleão dispôs em seu artigo 312: 'L'enfant conçu pendant le mariage a pour père le mari' ("o filho concebido durante o matrimônio tem por pai o marido"). É este o resultado final de três mil anos de monogamia (Ibid. p. 72-73).
\end{abstract}

Interessante notar que Engels coloca o adultério como um fator correspondente ao heterismo, como dois lados de uma mesma moeda. Dessa forma, procura ressaltar o adultério como uma contradição inerente à monogamia de cunho patriarcal. Ou seja, se a monogamia no patriarcado se relaciona à garantia da paternidade, ela 
esbarra na impossibilidade de assegurar seu próprio fim, uma vez que para isso é necessário o comprometimento da mulher. Para Engels, o comprometimento da mulher é abalado pelo heterismo e, portanto, o adultério aparece como "vingança" ou "resistência" feminina.

Para Engels, o adultério é, também, fruto de casamentos por conveniência e representa o amor sexual individual. Esse amor, segundo o autor, se oporia ao eros dos antigos porque supõe a reciprocidade, colocando homem e mulher no mesmo patamar. Tal reciprocidade não é encontrada na antiguidade e no período medieval exceto pelo adultério, devido sobretudo à natureza dos casamentos, os quais se davam por conveniência, combinados pela família dos noivos. Para corroborar sua hipótese, Engels ressalta que o eros antigo não levava em consideração o sentimento da mulher e que, na idade média, o amor exaltado pelos trovadores não era o amor conjugal, mas era sobretudo o amor ilícito configurado em adultério. Engels também identifica o amor sexual individual no proletariado, uma vez que não reconhece a monogamia clássica para esse grupo'.

Voltando à citação acima, nota-se que Engels levanta dois pontos importantes: 1. a criminalização do adultério para assegurar o comprometimento feminino, 2. a paternidade pelo convencimento moral. Essas seriam as duas formas que as sociedades patriarcais encontraram para resolver a contradição inerente postulada pela monogamia e sua ineficácia em assegurar a paternidade.

Engels, ao analisar as desigualdades entre os sexos no contexto monogâmico, dá visibilidade para o tema e contribui colocando questões fundamentais que serão desenvolvidas pela historiografia feminista do século $X X$.

Uma questão latente era a de como se dava exatamente o controle e regulamentação dos corpos das mulheres, pontos não muito explorados por Engels. Em The creation of patriarchy (1986), a historiadora Gerda Lerner retoma o trabalho de Engels e argumenta que instrumentos analíticos do marxismo seriam suficientes para compreender essa e outras questões. Por exemplo, Lerner argumenta que o conceito de classe seria o ponto chave para entender a função de homens e mulheres na formação do patriarcado na Mesopotâmia:

A subordinação sexual das mulheres foi institucionalizada nos mais antigos códigos de leis e era reforçada pelo poder estatal. A cooperação das mulheres no sistema era assegurada de várias maneiras: por meio da força, da dependência econômica ao homem chefe-de-família, por privilégios de classe e honras que conformavam como dependentes as mulheres de classes altas, e por meio da divisão artificialmente criada entre mulheres respeitáveis e mulheres não-respeitáveis.

Classe, para homens, era, e é, baseada no seu relacionamento com os meios de produção: aqueles que possuem os meios de produção podem dominar aqueles que não os possuem. Para mulheres, classe é mediada através de seus laços sexuais com um homem, aquele que então fornece a elas acesso a recursos materiais. A divisão de mulheres entre "respeitáveis" 
(isto é, vinculadas a um homem) e "não respeitáveis" (isto é, não vinculadas a um homem ou livre em relação a todos os homens) é institucionalizada em leis relacionadas ao uso do véu por mulheres (LERNER, 1986, p. 9)².

Lerner argumenta que o conceito de classe para mulheres se deu por meio da vinculação do status econômico e sexual. Tal vinculação resultou na divisão das mulheres em duas classes distintas: das mulheres respeitáveis e das mulheres não respeitáveis (1986, p. 121-122). Lerner argumenta, também, que a apropriação das capacidades reprodutivas das mulheres pelos homens se deu antes mesmo da consolidação da propriedade privada. Estados arcaicos eram já organizados de forma patriarcal e demonstravam interesse em manter as famílias nesse modelo. Tal interesse se concretizou na crescente institucionalização do controle da sexualidade feminina, como é possível perceber nos códigos de leis mesopotâmicos analisados pela autora.

Ao descrever os fundamentos de sociedades mesopotâmicas que demonstraram as primeiras características patriarcais, a autora faz apontamentos sobre a historiografia e entra no debate conceitual sobre o patriarcado, buscando fornecer uma definição geral do fenômeno:

Sociedade patriarcal é caracterizada pela descendência patrilineal, leis sobre propriedade garantindo os direitos dos filhos à herança, dominação masculina no que diz respeito à propriedade e às relações sexuais, e às burocracias militares, políticas e religiosas. Estas instituições eram suportadas pela família patriarcal, que por sua vez constantemente a recriava (LERNER, 1986, p. 106) ${ }^{3}$.

A partir dessas características, identificadas em sociedades do passado, Lerner cunha uma definição mais ampla, e coloca como patriarcado "A manifestação e institucionalização da dominação masculina sobre as mulheres e crianças na família e a extensão dessa dominação sobre as mulheres na sociedade como um todo" (p. 239)4.

Essa definição, que já vinha sendo utilizada quando a própria Lerner a criou, surge de um contexto de militância feminista dentro e fora da academia, e também de crise das teorias evolucionistas surgidas no século XIX, protagonizadas por Engels, Bachofen e outros autores, os quais postulavam a existência de um direito materno (matriarcado) que teria sido substituído por um direito paterno (patriarcado). Tal hipótese deu origem a um amplo debate, ainda em vigência, que questiona a existência do matriarcado como etapa comum e anterior à organização da forma patriarcal em várias sociedades antigas. Atreladas a este debate surgem análises elogiosas ao patriarcado antigo fundamentado em unidades familiares e agrícolas, contrapondo-o à decadência da vida urbana ${ }^{5}$. É, em parte, para se contrapor a essa tendência, para se desvencilhar do debate evolucionista, e, principalmente, para destacar as opressões de cunho patriarcal das sociedades modernas e contemporâneas, que muitas feministas começaram a utilizar uma definição como a de Lerner. 
Essa definição demonstra clara continuidade com a acepção de patriarcado utilizada por autores como os supracitados, Engels e Bachofen, entretanto se vincula com a militância feminista na medida em que se relaciona com a identificação de estruturas e elementos que compõem um conjunto de opressões a serem combatidas na atualidade.

O termo "patriarcado" vem sido alvo de muitas críticas, gerando um extenso debate no âmbito das discussões teórico-feministas, pondo seu uso em questão. A principal crítica é de anacronismo. Alguns afirmam que o termo surgiu como forma de designar sociedades específicas do passado e deve ser utilizado apenas com essa finalidade. Esta afirmação se baseia em uma crítica muito forte ao uso indiscriminado do termo para designar as formas de dominação masculina na atualidade. Este último uso foi denominado de "uso adjetivado" do termo, que seria, então, um uso estendido do termo como categoria histórica.

O uso adjetivado, por sua vez, vem gerando grande polêmica. Além de ser rotulado como anacrônico, o uso do termo patriarcado associado a sociedades do presente tem sido apontado como recurso insatisfatório para a escrita da História na medida em que não é apresentado de forma homogênea, ou seja, não há consenso conceitual e rigor em sua definição e aplicação (MORGANTE, 2014, p. 286).

Alguns argumentam que a palavra patriarcado designa "apenas uma das manifestações históricas da dominação masculina” (MIGUEL, BIROLI, 2014, p.18). Em função disso, preferem outras expressões, como "Viriarcado" e "Sociedade Falocêntrica”, ou, como Bordieu, utilizam a expressão de cunho mais neutro: "dominação masculina". Desta forma, alega-se que "dominação masculina" "seria mais correto e alcançaria um fenômeno mais geral que o patriarcado” (Ibid. p. 19).

Ainda uma terceira crítica ao uso do patriarcado diz respeito à assimetria das relações entre os gêneros, já implícita no termo. Desta forma, alega-se que o uso do termo encobre as nuances e especificidades das desigualdades constituídas a partir das relações entre os gêneros, que podem variar no tempo e no espaço. Neste sentido, advoga-se que a categoria "gênero", entendida como categoria de análise histórica, deve ser preferida.

Entretanto, teóricas feministas, como por exemplo Saffioti, ressaltam que ambas categorias, patriarcado e gênero, são igualmente válidas, e que o uso de uma não exclui a outra, muito pelo contrário, são complementares. Saffioti demonstra grande preocupação com o abandono do termo e destaca que: "Colocar o nome da dominação masculina - patriarcado - na sombra significa operar segundo a ideologia patriarcal, que torna natural essa dominação-exploração" (SAFFIOTI, 2004, p. 56).

Neste sentido, Saffioti destaca que o uso do termo por si só revela grande importância, uma vez que ele dá conta de expressar um conjunto de opressões geradas pela hierarquia construída por meio das relações de gênero, que se manifestam em todo os espaços da sociedade; e também porque "representa uma estrutura de poder baseada tanto na ideologia quanto na violência" (Ibid. p. 58). Ou seja, o próprio uso do termo evidencia relações de desigualdade e violência, colocando-se como recurso útil para a militância feminista, seja no âmbito da escrita da História, seja em 
um âmbito mais geral. Neste sentido, compreendemos que o conceito patriarcado representa um ponto de contato - muitas vezes necessário - entre a produção acadêmica e o ativismo.

Os argumentos de Saffioti vão de encontro daqueles de C. Pateman, que também ressalta a pertinência do termo patriarcado, destacando que deve haver um nome para o problema, pois deixar de nomeá-lo auxilia na sua "invisibilidade" (PATEMAN, 1988, p. 20).

O uso do termo patriarcado, resguardando suas especificidades históricas, apresenta grande relevância na medida em que marca um fenômeno. Deste modo, mostra-se como ferramenta metodológica, uma vez que, a partir desta concepção, do patriarcado como um fenômeno, podemos analisar de que forma os indivíduos agem e reagem em sua função.

Compreender o patriarcado como um fenômeno, ou mero instrumento analítico, torna-se importante no combate dos estereótipos de gênero. Uma das críticas ao termo diz respeito à perpetuação dos estereótipos da mulher vítima e do homem agressor. Alega-se então que o termo patriarcado dá primazia à assimetria entre homens e mulheres, encobrindo outras assimetrias que são construídas entre homens e entre mulheres, e que também se apresentam como dispositivos de violências de gênero. Além disso, o termo também encobriria as relações de igualdade e autonomia entre homens e mulheres, dificultando assim a identificação e valorização dessas relações.

Por outro lado, pensar as relações de gênero sob a ótica patriarcal pode dar visibilidade ao fenômeno. É neste sentido que Saffioti advoga ser necessário analisar as "relações da ordem patriarcal de gênero", de modo a compreender as várias articulações que levam à opressão das mulheres. Estas articulações se apresentam de várias formas e não se manifestam apenas nas relações entre homens e mulheres. Por exemplo, elas se manifestam também nas relações entre mulheres e entre homens, relações estas de fundamental importância para a construção das identidades de gênero subjetivas dos indivíduos. Ou seja, as relações de ordem patriarcal perpassam as relações sociais. É mais ou menos neste sentido que Saffioti descreve a "máquina patriarcal" como algo que funciona, em muitas situações, de maneira independente do exercício do poder pelo homem (SAFFIOTI, 2004, p. 102). Como exemplo, Saffioti destaca que a máquina pode, inclusive, ser acionada por mulheres. Isto fica claro, por exemplo, no modo como as mulheres, ignorando a violência de gênero nas relações dentro de sua categoria, são, muitas vezes, estimuladas a rivalizar umas com as outras, e também a vigiar e punir.

Dessa forma, é importante ressaltar que o entendimento do patriarcado como fenômeno se mostra relevante no sentido de auxiliar a identificar as várias formas de violência de gênero acionadas pelos modos dos indivíduos se relacionarem, e, consequentemente, identificar se estes modos estão pautados na ordem patriarcal de gênero, reproduzindo-a.

Se, por um lado, o termo patriarcado vem sido abandonado por historiadores e outros profissionais das Ciências Humanas, por outro lado, ele continua vivo no ativismo 
feminista, por se mostrar um conceito que unifica as opressões no campo da experiência feminina. Ou seja, ele se mostra como fator aglutinador de lutas feministas em nível global, por ser capaz de associar experiências individuais a processos históricos.

Entretanto, para que sejam observadas as especificidades históricas desse fenômeno, torna-se necessária a sua constante historicização. As sociedades antigas apresentam variadas formas de organização política e social, com diferentes noções de crime e gênero.

Voltando para o contexto romano da virada do primeiro século, quando a aristocracia da cidade de Roma se mostrava dividida em apoiar ou não a reforma moral empreendida por Augusto, percebemos que a discordância se dava por uma questão específica: a redefinição do papel do pater familias no julgamento dos casos de adultério, principalmente no que diz respeito à punição das mulheres.

Uma das principais novidades da 'Lei Júlia sobre adultério' foi a criação de uma corte especial e permanente (quaestio perpetua) para o julgamento público, por júri, dos casos de adultério. A lei ganha repercussão sobretudo porque transfere o julgamento dos adúlteros da jurisdição do pater familias para uma jurisdição, digamos, pública. A partir deste momento, um pater familias deveria dar entrada com um processo público contra a esposa ou a filha que cometesse adultério.

Esta institucionalização da punição deu mais visibilidade ao adultério porque determinava a retirada do direito de punição direta dos homens sobre as mulheres, transferindo esta responsabilidade para o aparato público, situando o adultério junto a outros crimes que este aparato já atendia, como, por exemplo, corrupção e fraude eleitoral e ofensas violentas como homicídio, açoitamento, invasão de domicílio, etc.

Entende-se, então, que a 'Lei Júlia sobre adultério' representa a transferência da punição do adultério da jurisdição doméstica, regida sobretudo pelos costumes, para a jurisdição pública, regida por leis e amparada por uma burocracia jurídica, digamos, 'estatal'. Tal transferência não parece ter sido completa e efetiva, entretanto demonstra o grau de importância atribuído à castidade feminina, ou seja, à pudicitia, por ser alvo de regulamentação no âmbito do direito criminal.

Como ressalta R. Langlands, a pudicitia (e seu oposto, a impudicitia) é um conceito ético que se coloca como um conceito chave para o entendimento da moral romana. Um dos motivos disso é que a pudicitia não estava relacionada exclusivamente ao comportamento feminino, mas também ao masculino, principalmente porque se considerava que ambos deveriam zelar pela castidade da mulher. A pudicitia é considerada como um conceito específico da sociedade e cultura romana, sem precedentes ou relativo gregos (LANGLANDS, 2006, p. 2).

A pudicitia era, também, uma divindade personificada em deusa, de culto popular em Roma e relacionada à proteção das crianças, jovens e mulheres casadas e livres (pueri, iuvenes, matronae). Essa relação de proteção evidencia o caráter vulnerável desses grupos e, ao mesmo tempo, os situa como grupos intocáveis, no sentido de que a violação desses corpos se configurava como ofensa grave. 
A pudicitia era uma virtude relacionada à integridade e pureza (sincerus) desses grupos e exigia a identificação visual deles (Ibid. p. 41). Nesse sentido, nota-se que a pudicitia tinha como característica essencial a demonstração, ela precisava ser mostrada e vista. E, dessa forma, relacionava-se a comportamentos, costumes e maneiras que não tinham exatamente uma natureza sexual, como, por exemplo, o modo de se vestir, a forma de se gesticular, o uso do espaço e da linguagem, os quais se configuravam como meios de comunicar a virtude (Ibid. p. 5). Ou seja, embora seja uma virtude pessoal relacionada ao pudor e ao recato, a pudicitia era algo de natureza pública principalmente no sentido de que deveria ser mostrada a todos.

Percebe-se, então, que a pudicitia era uma virtude que indicava integridade moral e física. Isto se torna evidente quando a compreendemos como um conceito subjetivo e um atributo do corpo. Representa um conceito subjetivo na medida em que a busca por esta virtude revela uma força de natureza moral que conduz a ações individuais e, um atributo do corpo, porque era este que devia ser controlado e protegido. A proteção da pudicitia envolve aqueles que estão próximos ao corpo que deve ser guardado. É deste modo que esperava-se que os homens, principalmente aqueles que possuíam mulheres sob sua tutela, zelassem pela pudicitia delas (LANGLANDS, 2006, p. 93; JOSHEL, 2002, p. 174; DIXON, 2001, p. 50).

Nota-se que a 'Lei Júlia sobre adultério' reforça esta expectativa. Tal reforço se dá em, principalmente, dois sentidos: 1. no sentido da definição do papel de homens e mulheres no que diz respeito à prática e punição do adultério; 2 . no sentido da expansão da lógica patriarcal na medida em que a lei transfere e amplia a jurisdição do privado para o público, permitindo e estimulando o envolvimento de pessoas estranhas ao grupo familiar dos adúlteros.

A lei colocava pais e maridos como os principais responsáveis pela acusação de ambos os adúlteros (a esposa/filha e o amante). Eles eram coibidos a fazê-lo, a lei declarava que o pai ou marido deveriam entrar com a acusação dentro de sessenta dias. Passado esse período, o direito era estendido a terceiros por um prazo de quatro meses ou mais (Dig. 48.5, 4, 1). Se fosse provado que o marido estava obtendo ganhos com o adultério da esposa, ele poderia ser acusado de alcovitice (lenocinium).

O marido também era acusado de lenocinium se fosse provado que ele permanecia com a esposa depois do adultério (Dig. 48.5, 2, 2). Ou, ainda, ele também era acusado se recebia dinheiro em troca de não denunciar os amantes, ou fizesse qualquer acordo com esse fim (Dig. 48.5, 14). Ou seja, a possibilidade da delação por terceiros colocava pais e maridos em situação de alerta, estimulando-os e pressionando-os a denunciar esposas e filhas.

O direito de denúncia por parte de terceiros denota a concepção da guarda da pudicitia como dever coletivo. Interessante notar que isso revela uma extensão do poder do pater familias, ao mesmo tempo que demonstra interferências e limitações a essa mesma esfera de poder. É uma extensão no sentido de que algo que era da responsabilidade do pater familias passa a ser da responsabilidade de outros homens - somente homens com mais de 25 anos poderiam entrar com a denúncia (Dig. 48.5, 15, 6). 
Nota-se, também, que é um reforço da pudicitia como algo de caráter público. A responsabilidade de cultivar a pudicitia recai sobre todos, homens, mulheres e crianças, mas de modos diferentes. Essas últimas deveriam se manter castas ou por meio da abstinência de relações sexuais ou, no caso das mulheres casadas, mantendo relações apenas com o marido. E os homens deveriam vigiar não só as mulheres pertencentes ao seu grupo familiar, como também as mulheres de outras famílias. No entanto, a lei, por meio da possibilidade de delação por terceiros e acusação de crime de alcovitice, culpabiliza os maridos pelas ações das esposas. Além disso, reforça a ideia de que mulheres deveriam permanecer sob tutela e vigilância. Desse modo determina papeis muito claros relacionados ao gênero: mulheres deveriam permanecer castas ao manter relações sexuais somente com os maridos, e homens deveriam vigiar as mulheres - ambos eram sujeitos à punição.

A lei estimula pais e maridos a cumprir funções de vigiar e punir mulheres relacionadas a eles, mas, ao mesmo tempo, limita os modos de punição, além de prescrever constrangimentos aos próprios homens. Tais constrangimentos podem ser entendidos como uma limitação e tolhimento do poder do pater familias. Estas medidas paradoxais apresentadas pela lei nos conduzem a uma dúvida central: teria a lei representado um reforço do patriarcado e da opressão às mulheres? Ou, pelo contrário, significou proteção às mulheres por meio da limitação do poder masculino? Vejamos:

Uma das principais limitações do poder diz respeito às circunstâncias previstas na lei segundo as quais o pater familias poderia matar a adúltera. A lei determinava que somente o pai podia matar a filha adúltera (Dig. 48. 5, 23). Este direito ao assassinato de outrem, chamado ius occidendi, tem origem na patria potestas (poder do pai). Inclusive, somente o pai que tinha a filha sob a patria potestas dele poderia exercer o ius occidendi, de modo que era negado ao homem que estivesse sob a tutela de seu pai - e, portanto, não possuía, ele mesmo, a patria potestas (Dig. 48. 5, 20; Paul. Sent. 2, 26, 2; Coll. 4, 12, 2) ${ }^{6}$. O pai da adúltera só poderia exercer o ius occidendi caso a filha fosse pega em flagrante delicto e na residência dele ou do marido (Dig. 48. 5, 23, 2). Ainda, para exercer tal direito, ele deveria matar ambos os amantes sem demora. Se ele matasse somente o homem e poupasse a vida da filha, ele poderia ser acusado de homicídio (Dig. 48. 5, 32). O marido não podia matar a esposa em hipótese alguma. A razão desta diferença quanto aos direitos determinados pela lei ao pai e marido é explícita no Digesto:

É dado ao pai, e não ao marido, o direito de matar a mulher e qualquer adúltero, porque, em geral, a afeição paternal é solícita aos interesses de seus filhos, mas o furor e a impetuosidade do marido, quem decide muito rápido, devem ser reprimidos (Dig. 48. 5, 22. 4). ${ }^{7}$

Interessante notar que a lei concede o ius occidendi ao pai com base na pietas dele. E, ao mesmo tempo, indica a ausência desta virtude na relação entre esposa e marido. Isto pode ser confirmado, por exemplo, em um outro trecho da lei, a respeito de quem detinha a preferência para dar seguimento à acusação da mulher: 
Se o marido e o pai da mulher aparecerem ao mesmo tempo com o propósito de acusá-la, a questão que se coloca é: qual deles o pretor deveria dar preferência? A melhor opinião é que o marido deveria ter preferência porque acredita-se que ele levará a cabo o processo, uma vez que age motivado por uma dor maior (Dig. 48. 5, 2, 8). ${ }^{8}$.

O pai, além do ius occidendi, também tinha o direito de tratar o adúltero com injúria (contumelia) (Dig. 48.5, 22, 3). O marido poderia reter o adúltero em sua casa por no máximo vinte horas consecutivas a fim de obter e reunir provas e testemunhas (Dig. 48.5, 25).

Nota-se que as condições determinadas pela lei a respeito do ius occidendi sugerem uma proteção à mulher, pois fixa limites do direito de vida e morte do pater familias e proíbe o marido de matar a esposa. Entretanto, essa proteção é ambígua. Se, por um lado, restringe o direito ao assassinato de mulheres; por outro lado, coloca as mulheres sob uma intensa supervisão. E, de todo modo, é impossível especular sobre possíveis diminuições ou não de taxas de assassinatos de mulheres depois da promulgação da lei, simplesmente porque não temos documentos suficientes.

Desse modo, nota-se que é impossível afirmar que a lei teria representado uma proteção às mulheres. Importante notar, também, que é complicado falar a respeito de políticas de 'proteção' às mulheres quando se trata do império romano. Isso poderia incorrer em anacronismos ao adentrar em debates atuais que implicam no reconhecimento, por instituições públicas e/ou governamentais, da família e do ambiente doméstico como lugar primário de violência contra mulheres e crianças, levando a justificar a lei como um instrumento e força intermediadora (CORRÊA, 1981, p. 8) . $^{\text {. }}$

É preciso destacar também que esta vigilância é maximizada por uma noção de que toda mulher era uma potencial adúltera. Em Roma, a promiscuidade masculina não era questionada em termos de uma fidelidade recíproca, visto que a monogamia patriarcal somente exigia a exclusividade sexual para a mulher. Este caráter unilateral da monogamia patriarcal colocava a mulher como um agente que poderia causar uma disrupção na ordem e hierarquia social. Excetuando as prostitutas, toda e qualquer mulher poderia cometer adultério. Toda mulher, portanto, representava uma ameaça nesse sentido. Para minimizar esta constante e inevitável ameaça, a figura da adúltera deveria ser mostrada como algo que necessitava ser expurgado da sociedade. Para os romanos, existiam duas formas de expurgar esta figura: por meio da morte, e por meio da anulação do status da adúltera, que passará a ser uma prostituta.

A mulher condenada como adúltera pela Lei Júlia perdia o status de mater familias e era juridicamente igualada a uma prostituta. Deste modo, a adúltera entrava para o rol dos infames, grupo caracterizado por uma situação jurídica incerta e complexa. Além das adúlteras, faziam parte deste grupo também as prostitutas, os proxenetas, os atores e os gladiadores. Os infames careciam de fama (reputação) e podem ser basicamente divididos em dois grupos: aqueles que exerciam uma profissão infame, como os citados anteriormente, e aqueles condenados por algum crime, como no caso das adúlteras ${ }^{10}$. Entretanto, o status legal dos condenados classificados como 
infames poderia ser temporário, enquanto que o daqueles que praticavam ofícios infames tendia a ser permanente.

Não era permitido aos infames: fazer acusações, atuar como testemunhas e falar em nome de outros em uma corte, e se candidatar para magistraturas. Seus corpos podiam ser violados, torturados e mutilados com impunidade. Ulpiano especifica, inclusive, que eles não tinham direito de fazer acusações de adultério (Dig. 48, 2, 4).

A 'Lei Júlia sobre adultério' reconhece como legítimo o ato de matar a mulher. Esse direito não foi excluído, apesar de todas as condições colocadas ao pai, como vimos antes, o único que pela lei poderia pô-lo em prática. Podemos inferir que, independente das condições, o reconhecimento em si revela o poder simbólico e ideológico que age na naturalização de uma forma extrema de violência.

Antes da lei ser promulgada, a punição dos adúlteros era decidida em conselhos domésticos organizados pelos homens do grupo familiar da mulher, e eram um requisito para validar a autoridade do pai ou do marido na aplicação de multas, punições físicas ou morte dos adúlteros. Eles validavam, por exemplo, a potestas vitae necisque (poder de vida e morte), exercida pelo pater familias. A autonomia dos homens em exercer uma jurisdição doméstica se relacionava com o conceito de res publica. Ao julgar e punir agentes que estavam em desarmonia com suas funções sociais, eles cumpriam um dever para com a res publica.

A instituição deste consilium privado era algo intrínseco da res publica. A sua existência reforçava a ideia de que a família era parte ativa e responsável no que diz respeito à segurança de toda a comunidade (GAUGHAN, 2010, p. 34). Este exercício do poder paternal atribuía um equilíbrio à res publica porque situava deveres públicos nas mãos de indivíduos, e, portanto, fazia parte da noção de civitas romana (Ibid., p. 52)11.

O estudo do patriarcado e do direito romano vem estimulando historiadores a traçarem reflexões sobre a realidade brasileira, como nos mostra esse trecho de uma das últimas obras de Saffioti:

O importante reter é que a base material do patriarcado não foi destruída, não obstante os avanços femininos, quer na área profissional, quer na representação no parlamento brasileiro e demais postos eletivos políticos. Se na Roma Antiga o patriarca tinha direito de vida e morte sobre sua mulher, hoje o homicídio é crime capitulado no Código Penal, mas os assassinos gozam de ampla impunidade (SAFFIOTI, 2004, p. 106).

O tema da pudicitia em Roma revela um temor à infidelidade feminina. É ela que desencadeia acontecimentos e mudanças - ela justifica a violência masculina em vários sentidos: para defendê-la ou vingá-la. Esse desencadeamento parece ter sido assimilado de tal forma que foi subsidiado pela lei em forma de um privilégio que, hoje em dia, se mostra, por exemplo, na figura jurídica chamada "crime passional".

A expressão “crime passional” é recente, mas o fenômeno se apresenta também em sociedades distantes no passado. No caso de Roma, isto é evidente, por exemplo, 
quando tomamos conhecimento de que a desigualdade imposta pela 'Lei Júlia sobre adultério' ao pai e marido quanto ao direito de matar a mulher adúltera foi remediada no segundo século, ou antes, como aponta Bauman (1996, p. 33). É exposto, no próprio Digesto, que Antonino Pio (138-161) adicionou à lei uma medida visando atenuar a pena do marido que matasse a esposa adúltera:

O imperador Marco Aurélio e seu filho Cômodo declararam que: "Se o marido que pega em flagrante adultério a esposa e a mata, conduzido pelo ímpeto de sua dor, ele não estará sujeito à Lei Cornélia de sicariis". E, a este respeito escreveu o divino Pio estas palavras endereçadas a Apolônio: "Ele, que matou sua esposa, pega em flagrante adultério, e não o nega, pode ser concedido um último suplício, alegando ser muito difícil repreender a justa dor; mas, porque ele fez mais do que deveria para se vingar, ele deve ser punido. É pena suficiente, se humilior, ser sentenciado ao trabalho forçado perpétuo, e, se um honestior, ser relegado para uma ilha. ${ }^{12}$ (Dig. 48. 5, 38, 8)

Interessante notar que esta medida iguala a pena do marido assassino à do adúltero quando o primeiro é um honestior. Ou seja, se o marido pertencesse à categoria dos honestiores era prevista a mesma pena que já era prevista para o adúltero, o exílio em ilha. Honestiores representam uma categoria jurídica que se caracteriza por alguma distinção política ou militar, faziam parte dela, por exemplo, senadores, equestres, decuriões e veteranos e seus familiares. Tipos de punições eram determinadas de acordo com a oposição entre honestiores e humiliores, que eram aqueles que não possuíam tais distinções. Crucificação, tortura e outros castigos corporais eram mais aplicados aos humiliores.

No Brasil, já foi observado que o adultério se mostra como um argumento útil nos pedidos de redução de pena, tanto para homens quanto para mulheres. Contudo, nota-se que o estigma da infidelidade pesa mais sobre as mulheres do que sobre os homens. Ao analisar processos de crimes passionais ocorridos em vários lugares do Brasil no decorrer do século XX, M. Corrêa ressalta que o que se coloca em julgamento são muito mais as condutas sociais do que o crime de homicídio. A autora nota que essas condutas são baseadas em dois conceitos, de acordo com o gênero: o trabalho para os homens, e a fidelidade para a mulher. Desse modo, indica, por exemplo, a frequência da aprovação do pedido de atenuação de pena por homicídio nos casos em que se alegava que o homem tinha trabalho e cumpria com a função de provedor no lar. Entendia-se que ele cumpria sua função social. E, ainda, entendia-se que, de certo modo, se ele matou a esposa adúltera - e/ou o amante dela -, esta não estava correspondendo quanto ao cumprimento de seu dever, que era exclusivamente o da fidelidade. $\mathrm{E}$, de modo inverso, quando estava a mulher no banco de réu, analisavase do mesmo modo esses componentes relacionados ao gênero, e, se comprovado que a mulher foi 'infiel', maiores as chances de seu pedido de atenuação de pena ser recusado (CORRÊA, p. 80-82). 
Nesse sentido, percebe-se uma duplicidade de tratamento gerados pelo estigma do adultério feminino: ele é utilizado para reduzir a pena de homens acusados de homicídios de mulheres e, ao mesmo tempo, é utilizado para culpabilizar mulheres acusadas de crime da mesma natureza.

Embora a legislação busque garantir minimante a igualdade de gênero com relação aos deveres dos cônjuges, além de outros deveres, ela não é expressa de forma real pelo sistema jurídico. A diferença no tratamento quanto aos privilégios assegurados pela figura jurídica do crime passional, como mostrado acima, é um exemplo claro disso. O estigma da infidelidade feminina, fomentado por um duplo padrão de valores que atribui um sentido mais negativo ao adultério quando cometido pela mulher do que quando cometido pelo homem, encontra espaço para se perpetuar na estrutura jurídica do Brasil.

Neste contexto, nota-se que a inclusão do qualificador 'Feminicídio' no rol dos "Crimes Contra a Vida" no Código Penal brasileiro se apresenta como um avanço no sentido de que desvincula o ato de violência contra a mulher de sua situação afetiva/ conjugal. O Feminicídio foi incluído pela Lei n. 13.104, de 2015, se constituindo como crime "contra a mulher por razões da condição de sexo feminino"13.

A lei sobre feminicídio se coloca como uma continuidade da Lei n. 11.340 (Lei Maria da Penha). Trata-se de uma continuidade positiva no tocante ao ativismo feminista e aos avanços dos estudos de gênero, por uma série de razões.

O termo feminicídio surge, no contexto brasileiro, como uma expressão que tem por objetivo dar visibilidade à violência contra as mulheres. Tendo como base o termo genocídio, a palavra feminicídio visa chamar atenção para o fenômeno da violência de gênero e, principalmente, para a dimensão do extermínio de mulheres no Brasil ${ }^{14}$.

Embora o termo feminicídio tenha sido escolhido para marcar um fenômeno amplo, ele é comumente utilizado para significar um femicídio, ou seja, a morte de uma mulher específica. Este termo, femicídio, é a forma "generificada", ou seja, com distinção de gênero, da palavra homicídio.

O termo feminicídio busca atribuir caráter público à violência contra mulheres, tratada na maioria das vezes como "violência doméstica", ou seja, uma violência que estaria circunscrita ao âmbito privado.

De todo modo, feminicídio ou femicídio, ambos os termos foram cunhados para desconstruir estereótipos e combater abordagens que tendem a naturalizar, patologizar e individualizar os casos, tratando-os como crimes passionais, de modo a ocultar a sua verdadeira amplitude. Ou seja, tais termos surgem como tentativa de redefinir e reacender as discussões sobre as experiências das mulheres e sobre a responsabilidade dos homens (SOUZA, BARROS, 2016, p. 267).

Como ressaltam L. Souza e P. Barros, o uso do termo feminicídio faz parte dos avanços no campo do Direito Penal, que atua também em nível simbólico: 
A visibilização do gênero dentro dos homicídios contra as mulheres pode ter sua importância como uma das ferramentas aplicadas para alterar padrões de desigualdade, oferecendo uma atuação simbólica do direito sobre as relações de gênero. A criminalização consagra o papel simbólico de demonstrar que tal conduta é reprovável, sinalizando publicamente a questão. Seu efeito simbólico é um elemento importante de formação da identidade e escolhas dos sujeitos, tendo impactos diretos na liberdade e na relação entre os sujeitos. A simbologia é ínsita direito penal, não se confundindo com mero simbolismo. [...] Com a publicização da violência de gênero e a nomeação dos casos em que a dominação das mulheres pela sociedade machista chega ao ápice do assassinato, o recrudescimento do tratamento penal demonstra que comportamentos misóginos não serão aceitos (Ibid. p. 276).

Diferente da Lei Maria da Penha, a Lei do Feminicídio se apresenta como um esforço em direção às formas de punição que não fortaleçam a separação entre mulher/vítima e homem/agressor, por si só reflexo de um sistema penal patriarcal, que reforça estereótipos de masculinidade e feminidade, e há muito tempo vem situando a mulher como agente passivo, merecedor de uma tutela especial (Ibid. p. 274).

Por fim, destacamos que, ainda recentemente no Brasil, a mulher, quando adúltera, não era tida como vítima, de modo que não era amparada pela justiça, por não ser considerada "mulher honesta", condição prevista no Código Penal até 2005. Neste sentido, finalizamos com um trecho de M. Montenegro, que ressalta que:

A relação da mulher com o Direito Penal, historicamente, foi de controle da sua sexualidade. Tanto é assim que nunca existiu uma preocupação com a mulher no tocante ao polo ativo, mas sim em relação ao polo passivo, especificamente para a lei penal nos crimes contra os costumes. Nesses crimes a mulher só poderia ser vítima quando considerada honesta. Na verdade, a figura da mulher honesta ultrapassou os crimes contra os costumes e chegou até mesmo a ser discutida nos crimes contra a vida e contra a integridade física. Basta só recordar a figura da legítima defesa da honra, que justificou, até recentemente, a morte ou a lesão corporal da mulher adúltera. A mulher, quando considerada adúltera, era também desonesta, uma vez que, para a maioria dos autores de Direito Penal, bem como para a jurisprudência majoritária do Brasil, uma mulher que frequentasse mais de um leito não seria considerada honesta. Após inúmeras críticas e alterações legislativas, perdeu força a figura da legítima defesa da honra, que não é mais aceita nem na doutrina nem na jurisprudência e a condição de mulher honesta deixou, no ano de 2005, o Código Penal (MONTENEGRO, 2015, p. 195). 


\section{Referências}

BAUMAN, Richard. Crime and punishment in Ancient Rome. London and New York: Routledge, 1996.

CORRÊA, Mariza. Os crimes da paixão. São Paulo: Brasiliense, 1981. (Coleção Tudo é História, v. 33)

DIXON, Suzanne. Rape in Roman law and myth. In: Reading Roman Women. London: Bristol Classical Press, Duckworth, 2001.

ENGELS, Friedrich. A origem da familia, da propriedade privada e do Estado. Trad. Leandro Konder. Rio de Janeiro: Ed. Civilização Brasileira, 1975. (1a ed. 1891)

FOUCAULT, Michel. Subjetividade e Verdade (Curso no Collège de France 1980-1981). Trad. Rosemary C. Abílio. São Paulo: Martins Fontes, 2016.

GAUGHAN, Judy E. Murder was not a crime: homicide and power in the Roman Republic. Austin: University of Texas Press, 2010.

HIRATA, H.; LABORIE, F; Le DOARÉ H. \& SENOTIER, D. Dicionário crítico do feminismo. São Paulo: Editora UNESP, 2009.

JOSHEL, Sandra. "The body female and the body politic: Livy's Lucretia and Verginia". In: MCCLURE, Laura K. (ed.). Sexuality and Gender in the Classical World. Oxford: Blackwell Publishers, 2002.

LANGLANDS, Rebecca. Sexual morality in Ancient Rome. Cambridge: Cambridge University Press, 2006

LERNER, Gerda. The creation of patriarchy. New York/Oxford: Oxford University Press, 1986.

MIGUEL, Luis Felipe \& BIROLI, Flávia. Feminismo e política. São Paulo: Boitempo, 2014

MORGANTE, Mirela Marin. Mulheres, Gênero e Patriarcado: novas categorias da pesquisa histórica. Cadernos de História, Ano IX, n. 1, 2014.

MONTENEGRO, Marilia. Lei Maria da Penha: Uma análise criminológico-crítica. Rio de Janeiro: Ed. Revan, 2015.

PATEMAN, Carole. The sexual contract. Stanford: Stanford University Press, 1988.

SAFFIOTI, Heleieth I. B. Gênero, patriarcado, violência. São Paulo: Editora Fundação Perseu Abramo, 2004.

SOUZA, Luciano Anderson; BARROS, Paula Pécora. Questões controversas com relação à Lei do Feminicídio (Lei N. 13.104/2015). Revista da Faculdade de Direito da Universidade de São Paulo, v. 111, p. 263-279, 2016. 


\section{Documentos}

IUSTINIANI, Augusti. Digesta. Latin text edited by Theodor Mommsen and Paul Krueger. Berolini, 1870. (vol. II)

JUSTINIAN. The Institutes of Justinian. Translated into English by J. B. Moyle, D.C.L. of Lincoln's Inn, Barrister-at-Law, Fellow and Late Tutor of New College, Oxford. (Acesso online pelo Project Gutenberg: http://www.gutenberg.org/files/5983/5983-h/5983-h.htm)

PAULUS, JULIUS. Sententiarum receptarum libri quinque. (Acesso online: http://www. intratext.com/X/LAT0621.HTM)

\section{Notas}

1 lbid. p. 77-78: "Nas relações com a mulher, o amor sexual só pode ser, de fato, uma regra entre as classes oprimidas, quer dizer, em nossos dias, o proletariado, estejam ou não estejam autorizadas oficialmente essas relações. Mas, desaparecem também, nesses casos, todos os fundamentos da monogamia clássica. Faltam aqui, por completo, os bens de fortuna, para cuja conservação e transmissão por herança foram instituídos, precisamente, a monogamia e o domínio do homem [...]. A família do proletário já não é monogâmica no sentido estrito da palavra, nem mesmo com o amor mais apaixonado e a fidelidade mais absoluta dos cônjuges, e apesar de todas as bênçãos espirituais e temporais possíveis. Por isso, o heterismo e o adultério, eternos companheiros da monogamia, desempenham aqui um papel quase nulo; a mulher reconquistou, na prática, o direito de divórcio e os esposos preferem se separar quando já não se podem entender um com o outro. Resumindo: o matrimônio proletário é monogâmico no sentido etimológico da palavra, mas de modo algum em seu sentido histórico".

2 Tradução nossa. "Women's sexual subordination was institutionalized in the earliest law codes and enforced by the full power of the state. Women's cooperation in the system was secured by various means: force, economic dependency on the male head of the family, class privileges bestowed upon conforming and dependent women of the upper classes, and the artificially created division of women into respectable and not-respectable women./ Class for men was and is based on their relationship to the means of production: those who owned the means of production could dominate those who did not. For women, class is mediated through their sexual ties to a man, who then gives them access to material resources. The division of women into "respectable" (that is, attached to one man) and "not-respectable" (that is, not attached to one man or free of all men) is institutionalized in laws pertaining to the veiling of women."

3 Tradução nossa. "Patriarchal society featured patrilineal descent, property laws guaranteeing the inheritance rights of sons, male dominance in property and sexual relations, military, political, and religious bureaucracies. These institutions were supported by patriarchal family and in turn constantly recreated it."

4 Tradução nossa. "The manifestation and institutionalization of male dominance over women and children in the family and the extension of male dominance over women in society in general"

5 Verbete "Patriarcado", In: HIRATA, H.; LABORIE, F; Le DOARÉ H. \& SENOTIER, D. Dicionário crítico do feminismo. São Paulo: Editora UNESP, 2009, p. 173-178.

6 Os filhos, homens ou mulheres, permaneciam sob a tutela do pai ou avô até a morte destes ou até que o processo de emancipatio fosse realizado. Cf.: Inst. 127-135.

7 Tradução nossa. Ideo autem patri, non marito mulierem et omnem adulterum remissum est occidere, quod plerumque pietas paterni nominis consilium pro liberis capit: ceterum mariti calor et impetus facile decernentis fuit refrenandus. (Dig. 48. 5, 22. 4) 
8 Tradução nossa. Si simul ad accusationem veniant maritus et pater mulieris, quem praeferri oporteat, quaeritur. Et magis est, ut maritus praeferatur: nam et propensiore ira et maiore dolore executurum eum accusationem credendum est. (Dig. 48. 5, 2, 8).

90 melhor exemplo disso pode ser encontrado em nossa realidade brasileira, quando dispomos da recente Lei n. 11.340, de 7 de Agosto de 2006. Esta lei, mais conhecida como 'Lei Maria da Penha', reconhece a família como lugar primário de violência ao dispor primordialmente a respeito "Da violência doméstica e familiar contra a mulher". Cf.: http://www.planalto.gov.br/ccivil_03/_ato2004-2006/2006/lei/111340.htm

10 Sobre o caráter de infamia atribuído às adúlteras, ver: Dig. 23, 2, 43, 12-13, e 48, 5, 10.

11 O que entendemos aqui por civitas está um pouco além de uma reunião de cidadãos, seria, também, e principalmente, o conjunto de deveres do cidadão para com a res publica.

12 Tradução nossa. Imperator Marcus Antoninus et Commodus filius rescripserunt: "Si maritus uxorem in adulterio deprehensam impetu tractus doloris interfecerit, non utique legis Corneliae de sicariis poenam excipiet". Nam et divus Pius in haec verba rescripsit Apollonio: "Ei, qui uxorem suam in adulterio deprehensam occidisse se non negat, ultimum supplicium remitti potest, cum sit difficillimum iustum dolorem temperare et quia plus fecerit, quam quia vindicare se non debuerit, puniendus sit. Sufficiet igitur, si humilis loci sit, in opus perpetuum eum tradi, si qui honestior, in insulam relegari". (Dig. 48. 5, 38, 8)

13 Cf.: http://www.planalto.gov.br/ccivil_03/_Ato2015-2018/2015/Lei/L13104.htm\#art1

14 O Brasil está em quinto lugar no ranking dos países com as maiores taxas de feminicídio. Cf.: https:// nacoesunidas.org/onu-feminicidio-brasil-quinto-maior-mundo-diretrizes-nacionais-buscam-solucao/ Acesso: 20 Mar. 2019.

\section{DECLARAÇÃO DE FINANCIAMENTO}

A pesquisa que resultou neste artigo contou com financiamento da FAPESP (Proc. 12/19662-0).

Sarah Fernandes Lino de AZEVEDO possui graduação e mestrado em História pela Universidade Federal de Ouro Preto e doutorado em História Social pela Universidade de São Paulo, com estágio na Universidade de St Andrews, Escócia. É pesquisadora vinculada ao Laboratório de Estudos sobre o Império Romano (http://www.leir.fflch.usp.br), onde é vice-coordenadora. Atua como professora temporária de História Antiga do Departamento de História da USP, e realiza pós-doutorado nesse mesmo Departamento. Atua também como coordenadora do Messalinas - Grupo de Estudos sobre Gênero e Sexualidade na Antiguidade.

Recebido em 31 março 2019

Aprovado em 24 outubro 2019 